\title{
When agreement is for covert but not for overt: the case of ustedes plus second person plural inflections in Peninsular Spanish
}

\author{
Víctor Lara Bermejo \\ Universität Bern \\ victor.lara@rom.unibe.ch
}

Received: 08-06-2015

Accepted: 30-09-2016

\begin{abstract}
The Spanish spoken in western Andalusia is characterised by having a single second person plural pronoun (ustedes) (unlike the standard variety which possesses two) and by inducing two agreements (second person and third person). In this article, I propose an analysis of unagreement configurations that follows the big DP hypothesis of Uriagereka (1995) for clitic doubling constructions. That is, I argue that the overt subject is base generated in the complement of a big DP whose specifier is a silent pronoun (a pro). The overt subject moves to a topic position and the silent pro stays in the subject position. Agreement mismatches arise from the fact that both DPs can trigger agreement. Furthermore, I propose that the different patterns in agreement found with ustedes arise from the diachronic cycle through which overt subjects are first topics. I state that in the process of reanalysis of topics as subjects, there is an intermediate phase in which a big DP emerges. This DP structure contains two different pronouns (one overt and one covert) that can establish different agreement relations. Finally, when the topic is completely reinterpreted as the subject, its agreement spreads throughout syntax, making agreement mismatches disappear.
\end{abstract}

Keywords: Topicalisation, covert pronouns, big DP, person mismatches, Andalusian

Table of contents

1. Introduction

2. Theoretical foundations

3. Analysis
4. Conclusions

References 


\section{Introduction}

Standard Peninsular Spanish possesses two different pronouns to mark politeness when addressing a group of people. As table 1 shows, vosotros plus $2^{\text {nd }}$ person plural inflections $(2 \mathrm{pl})$ denote informality while ustedes plus $3^{\text {rd }}$ person plural inflections $(3 \mathrm{pl})$ are employed for formality.

Table 1: Standard $2^{\text {nd }}$ person plural pronouns system and their inflections

\begin{tabular}{|l|l|l|}
\hline & INFORMALITY & FORMALITY \\
\hline PRONOUN & Vosotros & Ustedes \\
\hline INFLECTION & $2 \mathrm{pl}$ & $3 \mathrm{pl}$ \\
\hline
\end{tabular}

However, the south-western part of Andalusia, in southern Spain, has eliminated this distinction, by favouring the usage of ustedes as the single pronoun in plural, regardless the degree of politeness. This levelling has been attested in five districts: Huelva, Cadiz, Malaga, Cordoba and Seville (Lapesa 1980, Alvar 1996, Carrasco Santana 2002, Cano 2004, Penny 2004, Menéndez Pidal 2005), and it induces both 2pl and $3 \mathrm{pl}$ agreements. Scholars do not agree in stating what syntactic elements adopt the $2 \mathrm{pl}$ and which ones adopt the 3pl. To illustrate, Alvar et al. $(1961-1965)$ affirm that reflexives and some verb tenses are construed in $3 \mathrm{pl}(1-2)$, whereas object clitics and possessives are inflected in $2 \mathrm{pl}(3-5)$.

(1) Ustedes se vais de viaje

(Spanish)

You-3PL REFL.3PL go-2PL.PRES.IND on trip

'You are going on a trip'

(2) Ustedes fueron de viaje

(Spanish)

You-3PL go-3PL.PRET.IND on trip

'You went on a trip'

(3) A ustedes os veo

(Spanish)

To you-3PL ACC.2PL see-1SG.PRES.IND

'I can see you'
A ustedes os
doy
las llaves
To you-3PL DAT.2PL give-1SG.PRES.IND the keys
'I give you the keys'

(Spanish)

Vuestros hijos están en el colegio

POSS.2PL children be-3PL.PRES.IND in the school

(Spanish)

'Your children are in the school'

Cano (2008) and Fontanella de Weinberg (1999), on the other hand, point out that even possessives adopt the $3 \mathrm{pl}(6)$, although object clitics still show $2 \mathrm{pl}$.

Los hijos de ustedes están en el colegio

(Spanish)

The children of you-3PL be-3PL.PRES.IND in the school

'Your children are in the school' 
More accurate research carried out by Lara (2012) on the basis of the data collected by the Linguistic Atlas of the Iberian Peninsula (ALPI), disseminated the geographical, grammatical and pragmatic factors that intervened in this phenomenon around the middle of the $20^{\text {th }}$ century (map 1).

Map 1: Extension of ustedes as the single 2pl pronoun and its agreements in the first half of the $20^{\text {th }}$ century (Lara 2012)

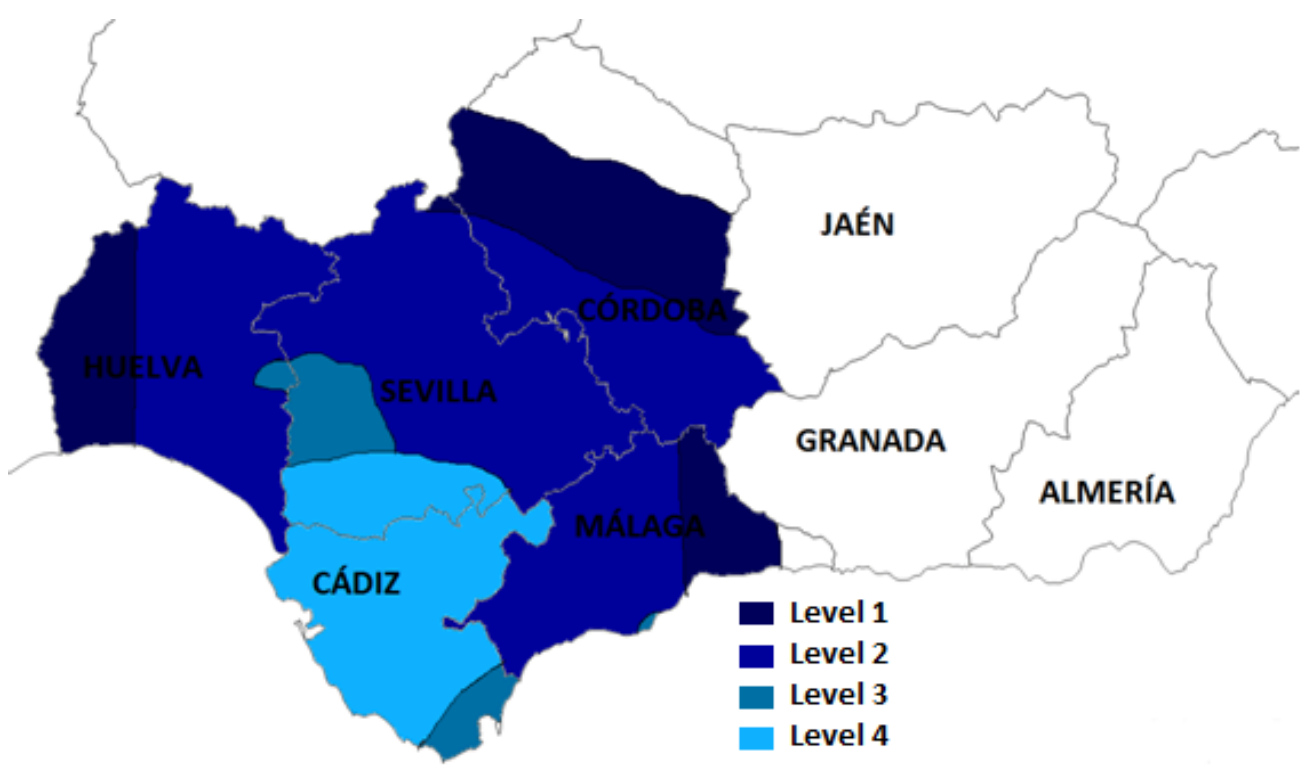

According to him, the generalisation of ustedes extended throughout Andalusia, following the wave model (Chambers and Trudgill 1980, Wolfram and Schilling-Estes 2003): this model states that when a given phenomenon emerges in a specific point, called focus or epicentre, it spreads to its outlying areas until it fades. Furthermore, every innovation that arises within the phenomenon is born in the same focus and it extends the same way as its previous innovations. Hence, the further away from the focus the more conservative the stages of the phenomenon are; on the contrary, the closer to the focus the more innovative the stages of the phenomenon are. In the ustedes phenomenon, Lara (2010 and 2012) found that the epicentre was southern Seville and virtually all the district of Cadiz. Likewise, this phenomenon produced four different innovations (levels), establishing a hierarchy throughout the syntax. This hierarchy, based on the extension of the $3 \mathrm{pl}$ with reference to ustedes, started in the stressed pronoun (level 1), shifted over to the reflexive (level 2), passed onto the accusative (level 3) and ended in the verb of an embedded sentence (level 4), as in (7) below.

$$
\text { Stressed pronoun }>\text { reflexive }>\text { accusative }>\text { embedded verb }
$$

The hierarchy must be read as follows: if the $3 \mathrm{pl}$ emerges in the accusative, then it also appears on the reflexive and the stressed pronoun. Once it is established in a certain stage, it can arise on the element of its right, always in this order. The impossibility of explaining the linguistic facts that this continuum produced, due to the scarce data of the corpus (Heap 2003), as well as the lack of occurrences in all the syntactic elements with reference to ustedes (datives, possessives, main verbs, etc.) has led to specific fieldwork across western Andalusia, in order to obtain quantitative and qualitative data about this phenomenon. 
The results of this fieldwork are conveniently presented in Lara (2015) and, on the whole, they show that the ustedes phenomenon prompts the gradual extension of the $3 \mathrm{pl}$ throughout the syntax, following the hierarchy represented in (8).

$$
\text { Stressed pronoun }>\text { reflexive }>\text { verb }>\text { accusative }>\text { dative }>\text { possessive }
$$

This hierarchy must be read as follows: if the $3 \mathrm{pl}$ is witnessed in the accusative, it must appear in the verb, the reflexive and the stressed pronoun. The establishment of the $3 \mathrm{pl}$ in one element presumes its emergence in the elements on the left but not on the right. Once the $3 \mathrm{pl}$ is completely established in one stage, it can go on rightwards in the hierarchy.

Even though the unagreement is significant in all the elements, I will focus on the mismatches attested between subject, reflexive and verb. Below I will describe the generative theory which deals with the possibility of finding unagreements and why they arise.

\section{Theoretical foundations}

Generative grammar sees verbal agreement as a relation of local dependence, in which the verb agrees with its arguments, as long as they are proximate or are found under the same phrase (Brucart and Hernanz 1987, Chomsky 1995, Eguren and Fernández Soriano 2004, Rodríguez Ramalle 2005, Bosque and Gutiérrez Rexach 2009). I propose that agreement mismatches emerge when the overt DP subject moves out of the VP to a topic position at the CP. Therefore, the moved element does not locally depend on the VP anymore. On the basis of this, I analyse sentence in (9) as follows (graphic 1):

$$
\begin{aligned}
& \text { Ustedes sois hermanos } \\
& \text { You-3PL be-2PL.PRES.IND siblings } \\
& \text { 'You are siblings' }
\end{aligned}
$$

Graphic 1: Representation of ustedes [pro 2 pl] sois hermanos

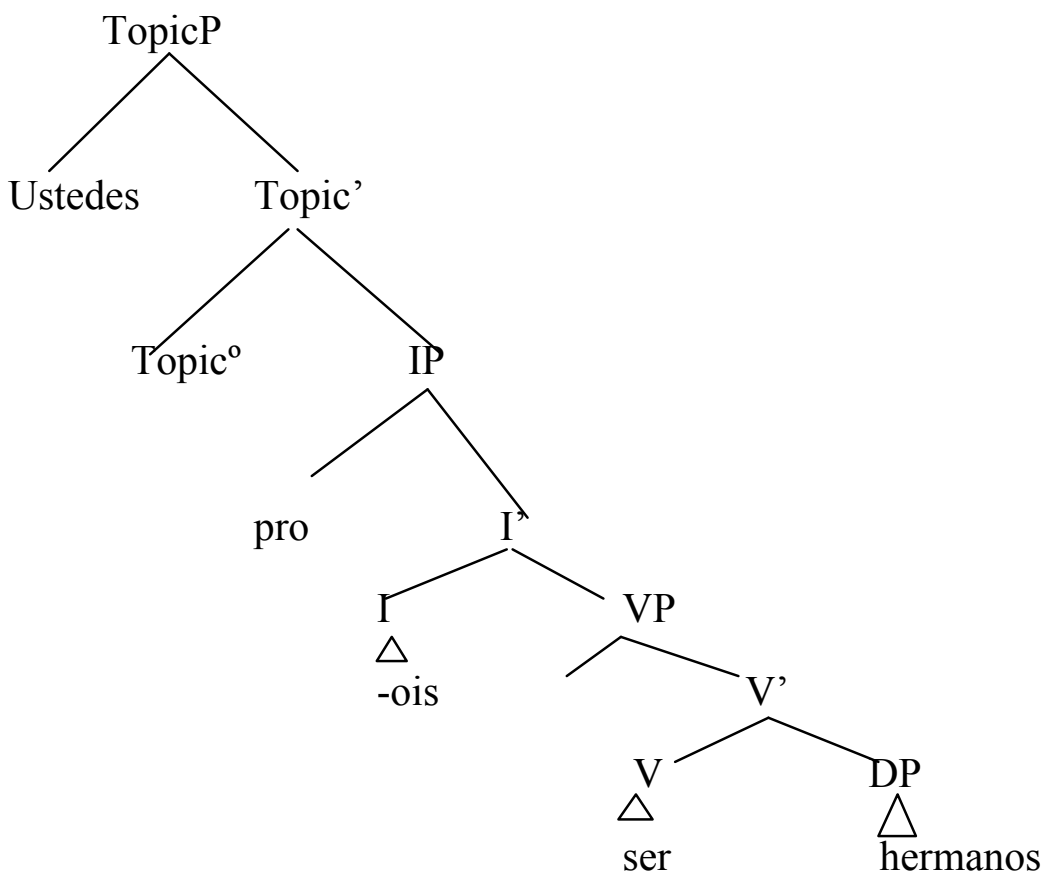


Taking into account that subjects originate within the VP (VP internal subject hypothesis, Koopman and Sportiche 1991), the VP of (9) contains a trace of the 2pl (the subject) that induces the agreement. Let us remember that, on the basis of the VP internal subject hypothesis, the inflectional phrase (IP) dominates the node I'. So, I' dominates I (the head) and the VP. Likewise, the VP dominates the the subject and the node $V^{\prime}$ and the latter dominates the verb as well as the internal arguments. In (9) a pro with $2 \mathrm{pl}$ features generated within the VP establishes agreement with I. The overt third person plural DP ustedes is located above the IP, in a topic position. The topic is located in the left periphery of the sentence, and this is why it has more independence when receiving agreement, as it is in a higher position than the IP. There are two sorts of topics, as will be explained below, but the independence I have referred to above may be owed to hanging topics (which are the ones that do not require agreement), unlike clitic left dislocated topics, which need mandatory agreement (Rizzi 1997).

To summarise, the sentence in (9) has the structure depicted in (10).

\section{[CP Ustedes [IP pro $_{2 \text { ndPL }}[\mathrm{I}$ sois hermanos ] ] ]}

As Spanish is a pro drop language, I propose that the overt DP is in a topic position and that there is a silent pronoun in subject position. This analysis has been repeatedly proposed in Spanish (Fábregas 2008 or Ordóñez and Treviño 1999).

The sentence in (11) shows an agreement mismatch between the subject and the verb. For this case, I propose that this mismatch emerges from the position of the students. The overt DP occupies the topic position at the CP (12).

Los estudiantes somos jóvenes

(Spanish)

The students be-1PL.PRES.IND young

'We students are young'

$\begin{array}{ll}\text { Los estudiantes, [pro } 1 \mathrm{pl}] & \text { somos jóvenes } \\ \text { The students [we] } & \text { be-1PL.PRES.IND young } \\ \text { ('We students are young') } & \end{array}$

The silent subject pro with 1st person plural features is generated within the VP and moves to the IP inducing the $1 \mathrm{pl}$ agreement with the verb. The overt DP "los estudiantes" is analysed as a particular type of topic, a hanging topic. Hanging topics usually prompt syntactic mismatches, as it is widely attested cross-linguistically (Borsley 1989, Olarrea 1995, Al-Shofarat 2012).

Spanish and Greek are studied in the majority of investigations about unagreement. Sentences like (11) have been recently analysed cross-linguistically by Ackema and Neeleman (2013), Costa and Pereira (2013), Choi (2013) or Höhn (2016). These analyses conclude that unagreement is mainly attested in pro drop languages. All previous investigations on unagreement involve mismatches between a definite third person DP and 1st or 2nd plural agreement. None of them deals with the unagreement analysed here, that is, the mismatch established between a stressed pronoun (not necessarily third person) and 1st, 2nd or 3rd plural agreement with the verb or a clitic. For instance, voseo, the use of the pronoun vos in the Spanish spoken in America mixes tuteo (the use of the pronoun tú) and voseo inflections. Some verb tenses adopt voseo inflections and other tenses prefer tuteo. The same accounts for clitics and possessives, which adopt tuteo (Fontanella de Weinberg 1979 and 1999, Abadía de Quant 1992, Bertolotti and Coll 2003, Hummel et al. 2010). The hybridism between ustedes and 2pl 
agreements presents a similar situation and the data analysed below will evidence that this mixture responds to topicalisation and to the gradual conversion of topics into subjects.

Bosque and Guitérrez Rexach (2009) divide topics in two different categories: hanging topics and dislocated topics. The former can only emerge in the left periphery, it must have a co-reference in the sentence and it does not need to possess the same syntactic features as its co-referent counterpart in the sentence, regardless the number, gender, case or person (13).

En cuanto al ordenador, yo odio

esas máquinas infernales

About the computer, I hate-1SG.PRES.IND these machines diabolical

('About / regarding computers, I hate these diabolical machines')

The latter (dislocated ones) introduce an identical theme as the one located inside the sentence, they make more prominent the thematic entity and, additionally, they can be formed by any phrase, as $(14-16)$ illustrate.
A Pepe, no lo
vi
ayer
To Pepe, no ACC.3SG.MASC see-1SG.PERF.IND yesterday
('To Pepe, I did not see him yesterday')

(Spanish)

En la mesa, no he

puesto nada

On the table, no have-1SG.PRES.IND put.PCP nothing

('On the table, I have not put anything on it')

$$
\begin{aligned}
& \text { Contento, no te diré que lo } \\
& \text { Glad, no DAT.2SG say-1SG.FUT.IND that 3SG.ACC.NEUT be-1SG.PRES.IND much } \\
& \text { ('Happy, I won't tell you that I am very happy') }
\end{aligned}
$$

All the themes must be recovered in the speech through a pronoun. This happens in (14) and (16) and, although (15) does not produce a visible anaphor in Spanish, French or Italian en / ne / y / ci recover the dislocated theme in their languages (Kayne 2003 and 2007). In Spanish, nonetheless, there is a silent pronoun. As can be seen in (13), the topic does not possess the same syntactic features as its anaphor, since the topic is oblique and its anaphor is accusative. Hence, the high position of topics in the whole structure grants them more independence regarding agreement than the elements within the IP.

Diachronically, topics are said to be reanalysed as subjects. According to Lehmann (1975), Li (1975), Givón (1990) or Hopper and Traugott (2003), the tendency of topics to be located in the left periphery prompts their reinterpretation as subjects, due to the fact that they are usually located in the non-marked position of subjects. Givón (1975) has traced the diachronic path through which a topic becomes a subject: firstly, the topic emerges out of the sentence and it is recovered by means of an anaphor inside the sentence (17).

Later, once this construction becomes unmarked, the topic co-occurs with its anaphor, so the topic has stopped being such and it is nearly a subject that still needs to be recovered by a reference. The anaphor becomes a sort of clitic subject (18). Notice that the coma that marks the prosodic pause between topic and sentence has been erased in the intermediate stage. 
Finally, the former topic turns into a real subject and, therefore, the anaphor disappears (19).

(19) The man came

(English)

Typological grammar has not been the single one to attest this sort of cooccurrence. The case of clitic doubling has also been studied from a theoretical perspective. Uriagereka (1995) has proposed the big DP hypothesis for clitic doubling configurations. According to Rubio Alcalá (2014), in clitic doubling, the DP is formed by an object clitic, which occupies the head position and a possible topic, which is the complement of this clitic. He draws the formation of a big DP structure of the sentence A Juan le regalaron un coche ('To Juan, they gave him a car') (graphic 2). Unlike him, Uriagereka (1995) or Papangeli (2000) however argue that the clitic-doubling is formed in the SpecDP.

Graphic 2: Formation of the big DP.

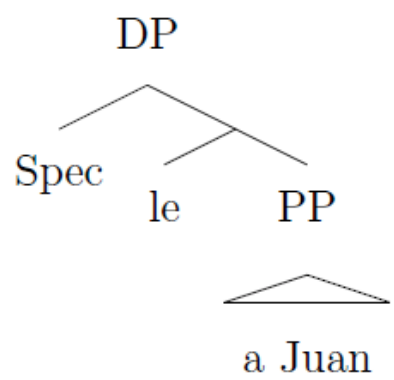

I propose an analysis of unagreement configurations in the spirit of Rubio Alcalá's (2014) clitic doubling structures: the overt DP subject is generated as the complement of $\mathrm{D}$ and it moves to a topic position in the left periphery of the sentence.

Diachronically, topics are reanalysed as subjects and agreement patterns change. Following Givón (1975), in the process of conversion of topic into subject, there is a stage in which two explicit elements with the same reference emerge. In fact, Real Academia Española (RAE) (2009) affirms that in some parts of Andalusia, in which ustedes has been levelled, there have been records of two concatenated pronouns, such as in (20).

$$
\begin{aligned}
& \text { Ustedes vosotros no la conocéis } \\
& \text { You-3PL. You-2PL no ACC.3SG.FEM know-2PL.PRES.IND } \\
& \text { 'You you do not know her' }
\end{aligned}
$$

Example (20) gives evidence that two coreferential pronouns can coexist, as predicted by the big DP hypothesis proposed here for the intermediate stage in the grammaticalisation of topics into subjects.

In section 3, I analyse the results of this research, in order to see whether the big DP hypothesis can account for the apparent unagreement patterns between subject and verb. Furthermore, I analyse the attested unagreement patterns with ustedes as an illustration of the grammaticalisation cycle, that converts topics into subjects and I will argue that these patterns in ustedes undergo three different phases: firstly, the existence of a base-generated topic (ustedes) that does not need to establish agreement ( $3 \mathrm{pl})$; secondly, the beginning of the conversion of ustedes into the subject, in which it 
coexists with the old subject, $2 \mathrm{pl}$ pro, within a big DP. This big DP can establish both $3 \mathrm{pl}$ and $2 \mathrm{pl}$; thirdly, the total conversion of ustedes into the subject with the disappearance of $2 \mathrm{pl}$ pro and the spread of the $3 \mathrm{pl}$ agreement.

\section{Analysis}

Before moving on to the results, I present below the figures of the fieldwork (table 2).

Table 2: Number of informants and occurrences

\begin{tabular}{|l|l|}
\hline INFORMANTS & OCCURRENCES \\
\hline 242 & 4,491 \\
\hline
\end{tabular}

As can be seen, approximately 4,500 occurrences have been recorded from about 240 informants all over western Andalusia. The method designed for obtaining data about this phenomenon has succeeded in collecting a large amount of occurrences. The informants were shown a series of muted sitcom scenes in which a person addressed a group. The surveyed had to dub spontaneously the character that talked to the rest. This method did not prime their response and prompted the emergence of all the syntactic features to be analysed (verb tenses, possessives, objects, etc.), since each scene prompted the expression of a specific syntactic element. Likewise, the scenes showed contexts in which the character had to be more formal and others in which the character could be more informal, so the scenes were also selected taking into account the degree of politeness, in case there might have been any grammatical difference due to diaphasic factors (Lara 2016).

Many of the agreement mismatches between pronoun and verb were produced because of topicalisation processes, as to be shown hereinafter. I will divide my analysis on the basis of the examples collected in the different geographical areas of the phenomenon and then I will discuss the linguistic behaviour of these instances.

Map 2: Current zones of the levelling of ustedes

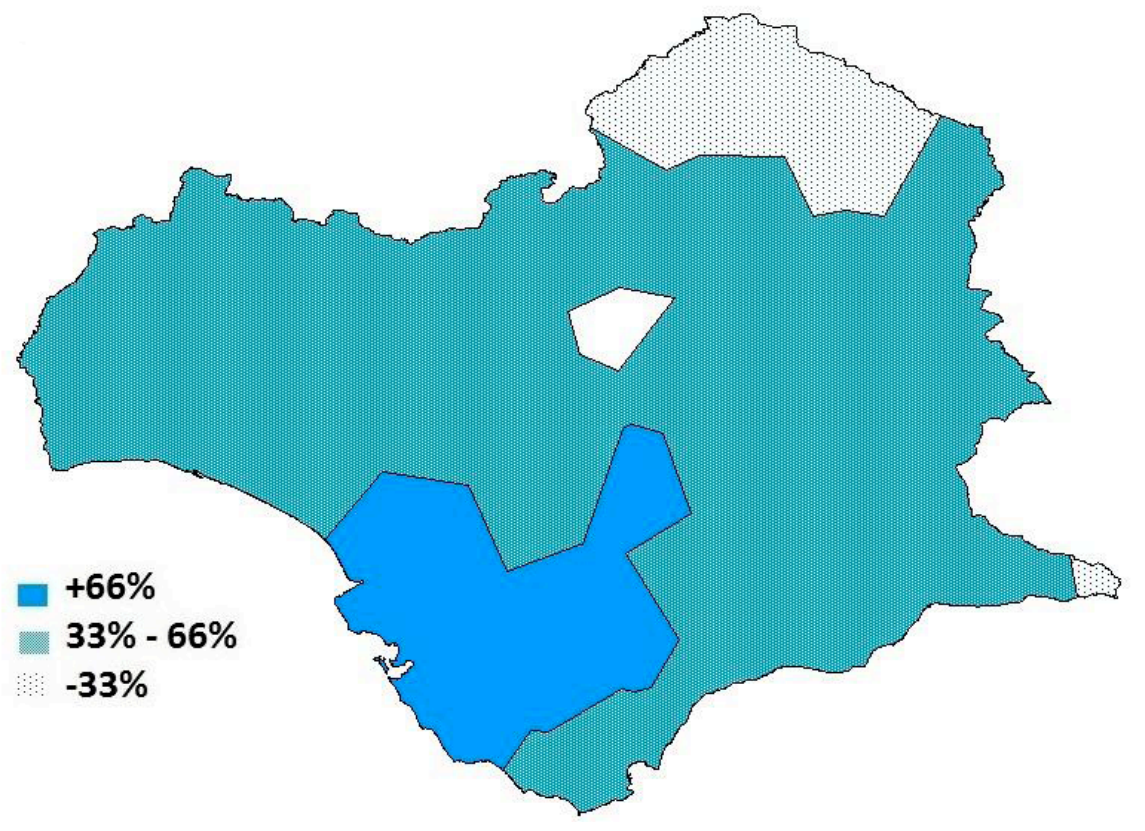


Map 2 shows that the use of ustedes as the single $2 \mathrm{pl}$ pronoun varies. Firstly, the zone with $+66 \%$ represents the area in which either the levelling is completely established or it is used by the majority of the speakers. Secondly, the zone characterised by the range of 33\% - 66\% represents an area with an intermediate usage of the levelling, whereas the zone with $-33 \%$ represents the area hardly affected by the levelling. The location characterised by $+66 \%$ is called focal area, while I will refer to the rest as peripheral areas.

\subsection{Peripheral areas}

The outlying zones around the focal area have expressed the highest number of unagreements, as shown in $(21-24)$.

$$
\text { Ustedes, no tenéis nómina }
$$

(Spanish)

You-3PL, no have-2PL.PRES.IND payroll

'You do not have any payroll'

(22) Ustedes, habéis desorganizado mi casa

You-3PL, have-2PL-PRES.IND mess up-PCP my house

(Spanish)

'You have messed up my house'

(23) Ustedes, no sois solvents

(Spanish)

You-3PL no be-2PL-PRES.IND solvent

'You are not solvent'
Ustedes, estáis
en paro
You-3PL, be-2PL.PRES.IND in unemployment
'You are unemployed'

However, the closer to the isogloss between periphery and focus, the more likely unagreements decrease and even co-occur with the $3 \mathrm{pl}(25-29)$.
$\mathrm{Se}$
os
queréis
ir
REFL-3PL REFL-2PL want-2PL.PRES.IND leave-INF

(Spanish)

'You want to leave'
$\mathrm{Se}$ os he
visto
ACC-3PL ACC-2PL have-1SG.PRES.IND see-PCP

(Spanish)

'I have seen you'

Hacer lo que se os dé la gana

Make-INF what DAT-3PL DAT-2PL want-3SG.PRES.SUBJ

(Spanish)

'Make whatever you want to'

The concatenation of two agreements is even attested in the verb, which shows in certain areas a root in $3 \mathrm{pl}$ and a desinence in $2 \mathrm{pl}(28-29)$.

$$
\begin{aligned}
& \text { Me abrierois los grifos } \\
& \text { DAT-1SG open-3PL+2PL.PERFC.IND the taps } \\
& \text { 'You opened the taps of my house' }
\end{aligned}
$$


Intentarois entrar

(Spanish)

Try-3PL+2PL.PERFC.IND come in-INF

'You tried to come in'

\subsection{Focal area}

Once we reach the focal area, the $3 \mathrm{pl}$ agreement is completely established between ustedes and the verb $(30-35)$.

(30) Ustedes, irse

(Spanish)

You-3PL, go-INF. REFL.3PL

'You, go away'

(31) Ustedes, ¿no estarían cotilleando?

(Spanish)

You-3PL, no be-3PL.COND gossip-GER

'Wouldn't you be gossiping?'

Son

ustedes las que entraron

en mi piso

(Spanish)

Be-3PL.PRES.IND you-3PL who enter-3PL.PERF.IND in my apartment

'You were the ones who entered my apartment'

Ustedes me han pedido un crédito

(Spanish)

You-3PL DAT.1SG have-3PL.PRES.IND ask-PCP a credit

'You have asked me for a credit'

(34) A ustedes, ¿qué les importa?

(Spanish)

To you-3PL, what DAT.3PL matter-3SG.PRES.IND

'Mind your own business'

\section{Inundaron \\ el piso}

(Spanish)

Flood-3PL.PFC.IND the apartment

'You flooded my apartment'

The fact that $3 \mathrm{pl}$ pronoun like ustedes can appear with a verb in $2 \mathrm{pl}$ has been analysed as a case of syncretism. That is, ustedes can also contain $2 \mathrm{pl}$ features because of its semantics. However, several facts contradict this analysis. Firstly, RAE (2009) states that in the area where ustedes agrees in $2 \mathrm{pl}$ there are records of linguistic sequences such as (20). The overt concatenation of both pronouns reveals that the pronoun vosotros has not completely disappeared, at least in certain areas. Indeed, the emergence of two pronouns is also attested in reflexives and object positions $(25-27)$.

The co-occurrence of vosotros and ustedes shows that vosotros is present somehow, since speakers need to express an agreement referred to ustedes (se) and another one to vosotros (os). If the syncretic analysis were correct, we would expect only 2 pl agreements. Indeed, $(25-29)$ is an argument in favour of my analysis: the person mismatches attested in $(21-24)$ correspond to the fact that the overt subject is actually a topic and that the real subject is a silent pronoun (phase 1).

Once the frequency of the topic construction prompts the beginning of the reanalysis of ustedes as the subject, the big DP is formed (phase 2). This big DP contains the new and the old subjects (ustedes and vosotros) that can trigger two agreements: sometimes covertly, sometimes overtly. Examples $(25-29)$ illustrate the agreement patterns that can be triggered by the big DP: one for ustedes and another one for $2 \mathrm{pl}$ pro. It is precisely in the intermediate stage witnessed by Givón (1975) in the 
path of topics into subjects, when the big DP shows overtly the two elements included in it. Notice that the composite agreement is not only attested in the pronouns, but also in the verbal inflection, which sums -ro ( $3 \mathrm{pl})$ plus $-i s(2 \mathrm{pl})$. It is in this stage when the conversion of the topic into subject coincides with the level of (18) (The man he came), since both elements emerge, regardless they are stressed or unstressed. The mismatches have been also attested in clitic left-dislocations $(3-4)$. In principle, clitic-doubling constructions must agree in case, gender, number and person (as Papangeli 2000 shows for Greek), but it is not true in peripheral areas of western Andalusian Spanish. This can only correspond to silent elements: again the pronoun vosotros. It is not the only case of silent pronouns attested cross-linguistically. Kayne (2005) has noticed this particularity in subjects after verbs of French relative sentences $(36-37)$.

La fille à qui a tout dit Jean-Jacques (French)

The girl PREP who have-3SG.PRES.IND everything say-PCP Jean-Jacques

'The girl to whom Jean-Jacques has said everything'

Le criminel qu' ont condamné trois juges

The criminal who have-3PL.PRES.IND convict-PCP three judges

'The criminal who three judges have convicted'

He also notes that subject clitics for third person are not obligatory $(38-39)$ in comparison to the rest of persons $(40-41)$ :

Lui (,)

a téléphoné

3SG.MASC (3SG.MASC.CLIT) have-3SG.PRES.IND phone-PCP

'He has phoned'

Eux (,) (ils) ont téléphoné
3PL.MASC (3PL.MASC.CLIT) have-3PL.PRES.IND phone-PCP
'They have phoned'

téléphoné

Moi, *(j')

ai

phone-PCP

'I have phoned'

$$
\begin{aligned}
& \text { Toi, *(tu) as téléphoné } \\
& \text { 2SG }(2 \mathrm{SG} . \mathrm{CLIT}) \text { have-2SG.PRES.IND phone-PCP } \\
& \text { 'You have phoned' }
\end{aligned}
$$

For this author, $(36-39)$ are characterised by having a silent or covert element which is not phonetically produced but which lies throughout the steps of the syntactic derivation. In the cases where the subject follows the verb, Kayne argues that the subject has moved out of the IP toward the specifier of a higher phrase (force phrase), leaving behind a trace in form of a subject clitic which is simply not made explicit. Indeed, as in clitic doublings, the subject after the verb is part of a wider DP headed by a silent subject clitic. Lambrecht (1980 and 1981) has also studied the subject clitics in French and their behaviour regarding dislocated elements as in $(42-43)$. 
Pièrre, il

mange

des pommes

(French)

Pièrre, 3SG.MASC.CLIT eat-3SG.PRES.IND PART apples

('Pièrre eats apples')

$$
\begin{aligned}
& \text { Il mange des pommes, Pièrre } \\
& \text { 3SG.MASC.CLIT eat-3SG.PRES.IND PART apples, Pièrre } \\
& \text { 'Pièrre eats apples' }
\end{aligned}
$$

For this author, this kind of structures reflects the topicalisation cycle postulated by Li (1975), who states that languages, from a typological point of view, are ordered regarding their information structure as follows: topic prominent (44); neither topic nor subject prominent (45 a-b); subject prominent (46); both subject and topic prominent (47).

(44) Chocolate, I prefer it dark

(English)

a) Aalisin ng-babae ang-bigas sa-sako para-sa-bata

(Tagalog) take out-FUT. woman rice sack child

b) Aalisan ng-babae ng-bigas ang-sako para-sa-bata take out-FUT. woman rice sack child

('A / The woman will take some rice out of the sack for a / the child')

(46) I work hard

(English)

(47) Peter, he loves running

(English)

While (44) always needs to express the aboutness, regardless of the subject of the sentence, (45 a - b) compares two Tagalog sentences (taken from Schachter 1975) that mean exactly the same. They are formed taking into account the thematic roles of the participants but the prefix ang can be positioned depending on the feature we want to emphasise. There are as many alternatives to put the prefix ang as thematic roles there are within the sentence. In (46), the subject (linked to the notion of agent or doer) is the important element, in comparison to (47), where both topic and subject must be expressed although they may refer to the same entity. French would be found in this last stage, in which the two elements are expressed.

Ordóñez and Treviño (1999) analyse the French examples as follows: the subject is a complex DP formed by a clitic and a DP. The DP moves up to the specifier of the node above the VP, while the subject clitic remains anchored in its original position.

Graphic 3: Big DP of a non-marked subject construction

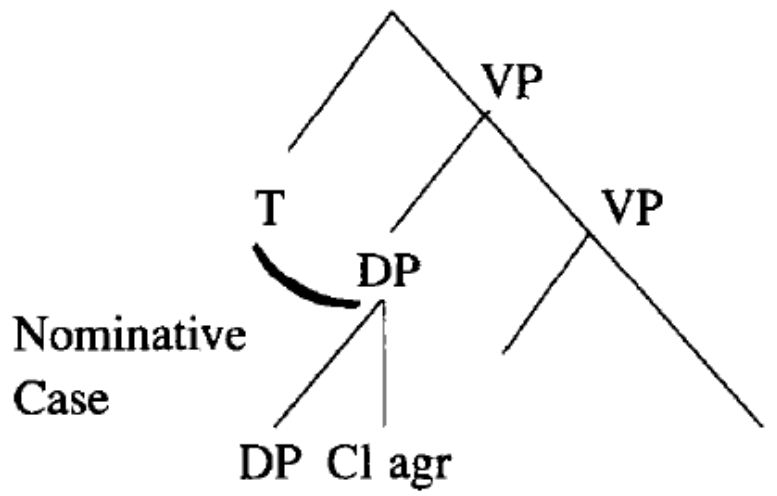


Therefore, we can take these examples in French as evidence in favour of the analysis put forth for Spanish. The difference between Spanish and French is that the subject clitics in Spanish are silent.

Finally, in phase 3, ustedes is completely reinterpreted as the subject. This becomes established when the speakers stop using vosotros and generalise the $3 \mathrm{pl}$ in all the verb tenses. Once ustedes is finally chosen and vosotros disappears, the informants generalise $3 \mathrm{pl}$ in reflexives and verb tenses and extend the agreement throughout the rest of syntactic elements: objects and possessives. Before this last stage, the $2 \mathrm{pl}$ agreed with a silent $2 \mathrm{pl}$ subject, vosotros. This is exactly what has happened in the focal zone, where the topic has become a subject and it emerges in the IP and not in the TopicP. Thus, the syntactic features must match, even when it is not the subject (34). Before this linguistic situation, the $3 \mathrm{pl}$ fought the $2 \mathrm{pl}$ to impose itself (see table 3 ).

Table 3: Phases throughout the ustedes phenomenon

\begin{tabular}{|l|l|l|l|}
\hline & Ustedes & Vosotros & Agreement \\
\hline Phase 1 & $\begin{array}{l}\text { Topic } \\
\text { (as in 'The man, he came') }\end{array}$ & Subject & $2 \mathrm{pl}$ \\
\hline Phase 2 & $\begin{array}{l}\text { Topic-subject } \\
\text { (as in 'The man he came') }\end{array}$ & Subject & $3 \mathrm{pl}+2 \mathrm{pl}$ \\
\hline Phase 3 & $\begin{array}{l}\text { Subject } \\
\text { (as in 'The man came') }\end{array}$ & Eliminated & $3 \mathrm{pl}$ \\
\hline
\end{tabular}

It is important to make clear that the composite agreement attested in the data always shows the co-occurrence of $3 \mathrm{pl}$ plus $2 \mathrm{pl}(25-29)$, and never the other way around. Neither scholars nor my corpus have collected sequences of $2 \mathrm{pl}$ plus $3 \mathrm{pl}$ and this can be explained by the fact that the innovative agreement $(3 \mathrm{pl})$ was trying to leave the conservative one $(2 \mathrm{pl})$ aside. Whenever a new linguistic use emerges, it tries to oust the existing one. Therefore, when a topic like ustedes is reinterpreted as a subject, it eliminates the existing one (vosotros) and it ends up establishing as the new subject. As ustedes needs to agree in $3 \mathrm{pl}$ and not in $2 \mathrm{pl}$ as vosotros, the $3 \mathrm{pl}$ must also be established as the new agreement in detriment of the previous $2 \mathrm{pl}$ agreement. Italian underwent a similar process regarding its third person pronouns. According to Rohlfs (1968) or Eernst et al. (2008), in the Early Middle Ages, the subject pronouns egli, ella, essi, esse ('he', 'she', and 'they' masculine and feminine respectively) were the normative third person subject pronouns. However, the object forms lui, lei and loro started coexisting with the former, first, as topics (48).

$$
\text { Lui, egli sa ogni cosa }
$$

Him he know-3SG.PRES every thing

'He knows it all'

With time, this construction was becoming common and the normative subject pronoun cliticised (49).

Lui e'sa ogni cosa

Him he know-3SG.PRES every thing

'He knows it all' 
Finally, the clitic disappeared and the previous object pronoun became the new subject pronoun as we know it today (50).

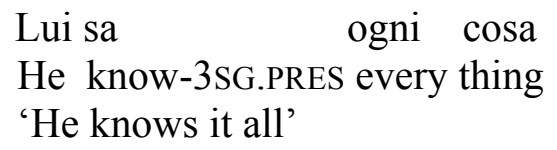

As happened in the ustedes phenomenon, the new form is placed in the left periphery and displaces the previous form always in that order, from left to right. In the phenomenon under study, the gradual imposition of ustedes and the $3 \mathrm{pl}$ over vosotros and the $2 \mathrm{pl}$ started covertly; then it emerged phonetically coexisting with the other one; later it shared verbal inflection and formed a hybrid morpheme; and finally it overthrew the $2 \mathrm{pl}$ only when it was induced by ustedes reanalysed as a subject, as (19) points out, in the conversion of topics into subjects.

Unlike the linguistic situation from nearly one hundred years ago attested in graphic 1 , nowadays ustedes already induces $3 \mathrm{pl}$ in the verb and the rest of elements. The phenomenon of ustedes has evolved significantly, in comparison to the results described in Lara (2010 and 2012). Last century, ustedes was still a topic, whereas nowadays it has turned into a subject in the focal area. Here, the pronoun vosotros has been completely eliminated from the paradigm.

\section{Conclusions}

The levelling of ustedes as the single $2 \mathrm{pl}$ pronoun has evolved dramatically since it was last recorded. In the middle of the $20^{\text {th }}$ century, this pronoun induced both $2 \mathrm{pl}$ and $3 \mathrm{pl}$ agreements, leading to person mismatches between subject and verb (see map 1). These unagreement patterns are only apparent since agreement is actually established with a silent pronoun, and not with the overt DP subject, which actually functions as a topic. As diachronically topics tend to become subjects, ustedes started to be reanalysed as such and, before achieving its goal, it coexisted with vosotros within the sentence. In this intermediate stage, ustedes and the silent pronoun formed a big DP, which could be completely overt only in peripheral areas close to the focal one. The emergence of the two agreements, $3 \mathrm{pl}$ and $2 \mathrm{pl}$, in this intermediate phase always followed the order $3 \mathrm{pl}+$ $2 \mathrm{pl}$. Even the verbal desinence was construed with a hybrid form of $3 \mathrm{pl}+2 \mathrm{pl}$. The focal area has turned ustedes into a complete subject, by agreeing in $3 \mathrm{pl}$ all its syntactic elements. Therefore, the apparent mismatches were produced by covert elements, since the agreement was not established with ustedes (which is analysed as a hanging topic) and the verb, but between a $2 \mathrm{pl}$ silent pronoun in subject position and the verb.

\section{References}

Abadía de Quant, I. 1992. "La relación pronominal-verbal de segunda persona singular en el español de Corrientes durante el siglo XIX, su comparación con la situación en Buenos Aires". Revista argentina de lingüistica 8: 31-46.

Ackema, P. \& Neeleman, A. 2013. "Subset controllers in agreement relations". Morphology 23: 291-323. https://doi.org/10.1007/s11525-013-9218-4

Adams, M. 1987. "From old French to the theory of pro-drop". Natural Language and Linguistic Theory 5 1: $1-32$. 
https://doi.org/10.1007/bf00161866

Al-Shorafat, M. 2012. "Subject-verb agreement in standard Arabic: a minimalist approach". Journal of theoretical linguistics $91: 33-48$.

Alvar, M., Llorente, A. \& Salvador, G. 1961-1965. Atlas lingüístico y etnográfico de Andalucía (ALEA). Granada: Universidad de Granada.

Alvar, M. 1996. Manual de dialectología hispánica. Barcelona: Ariel.

Bertolotti, V. \& Coll, M. 2003. "A synchronical and historical view of the tú/vos option in the Spanish of Montevideo". In Montrul, S. \& Ordóñez, F. (eds.), Linguistic theory and language development in Hispanic languages, 1-12. Somerville: Cascadilla Press.

Borsley, R. D. \& Stephens, J. 1989. “Agreement and the position of subjects in Breton". Natural Language and Linguistic Theory 7 3: 407 - 427. https://doi.org/10.1007/bf00208103

Bosque, I. \& Gutiérrez-Rexach, J. 2009. Fundamentos de sintaxis formal. Madrid: Akal. Brucart, J. M. \& Hernanz, M.L. 1987. La sintaxis. Barcelona: Crítica DL.

Cano, R. 2004. Historia de la lengua española. Barcelona: Ariel.

Cano, R. 2008. El español a través de los tiempos. Madrid: Arco Libros.

Carrasco Santana, A. 2002. Los tratamientos en español. Salamanca: Ediciones Colegio de España.

Chambers, J.K. \& Trudgill, P. 1980. Dialectology. Cambridge: Cambridge University Press.

Choi, J. 2013. "Pro-drop in pronoun-noun constructions". In Keine, S. \& Sloggett, S. (eds.), NELS 42: Proceedings of the 42nd meeting of the North East Linguistic Society, 119-128. Amherst: GLSA.

Chomsky, N. 1995. The Minimalist Program. Cambridge: MIT Pres.

Eguren, L. \& Fernández Soriano, O. 2004. Introducción a una sintaxis minimista. Madrid: Gredos.

Elvira, J. 1993. "La función cohesiva de la posición inicial de frase en la prosa alfonsí". Cahiers de linguistique hispanique médiévale 18/19: 243 - 278. https://doi.org/10.3406/cehm.1993.1089

Elvira, J. 1996. "La organización del párrafo alfonsí”. Cahiers de linguistique hispanique médiévale 21: 325 - 342. https://doi.org/10.3406/cehm.1996.881

Elvira, J. 2014. "Left forever: subject datives and clitic doubling in Old Spanish". In Dufter, A. \& Octavio de Toledo y Huerta, Á. (eds.), Left sentence peripheries in Spanish: diachronic, variationist and typological perspectives, 77 - 97. Amsterdam / Philadelphia: John Benjamins. https://doi.org/10.1075/la.214.06elv

Ernst, G. et al. (eds.). 2008. Romanische Sprachgeschichte. Berlin / New York: Mouton de Gruyter.

Fábregas, A. 2008. "Variación en forma morfológica de los pronombres de primera y segunda persona del plural". Revista española de lingüística 38: 155-184.

Fontanella de Weinberg, B. 1979. "La oposición cantes/cantés en el español de Buenos Aires". Thesaurus XXXIV, 1, 2 and 3: 72-83.

Fontanella de Weinberg, B. 1999. "Sistemas pronominales de tratamiento usados en el mundo hispánico”. In Bosque, I. \& Demonte, V. (dirs.), Gramática descriptiva de la lengua española, vol. 1, 1399-1425. Madrid: Espasa.

Givón, T. 1975. "Topic, pronoun and grammatical agreement". In Li, C. N. (ed.), Subject and topic, 149 - 188. New York: Academic Press Inc. 
Givón, T. 1990. Syntax, a functional-typological introduction. Amsterdam / Philadelphia: John Benjamins Publishing Company.

Heap, D. 2003. Atlas lingüistico de la península ibérica (ALPI). University of Western Ontario $<\mathrm{http}$ ://www.westernlinguistics.ca/alpi/>.

Höhn, G. F.K. 2016. "Unagreement is an illusion: Apparent person mismatches and nominal structure". Natural Language and Linguistic Theory 34, 2: 543- 592. https://doi.org/10.1007/s11049-015-9311-y

Hopper, P. \& Traugott, E. 2003. Grammaticalization. Cambridge: Cambridge University Press.

Hummel, M. et al. 2010. Formas y fórmulas de tratamiento en el mundo hispánico. Mexico DF: El Colegio de México / Karl-Franzens-Universität Graz.

Kayne, R. 2005. Movement and silence. Oxford: Oxford University Press.

Kayne, R. 2003. "Person morphemes and reflexives in Italian, French and related languages". In Tortora, C. (ed.), The syntax of Italian dialects, 102-136. Oxford: Oxford University Press.

Kayne, R. 2007. Some silent first person plurals. New York: New York University, 10th April 2007 https://doi.org/10.1093/acprof:oso/9780199553266.003.0015

Lambrecht, K. 1980. "Topic, French style: remarks about a basic sentence type of modern non-standard French". Proceedings of the sixth annual meeting of the Berkeley Linguistics Society: 337 - 360.

Lambrecht, K. 1981. Topic, antitopic and verb agreement in non-standard French. Amsterdam / Philadelphia: John Benjamins. https://doi.org/10.1075/pb.ii.6

Lapesa, R. 1980. Historia de la lengua española. Madrid: Gredos.

Lara, V. 2010. El uso de ustedes por vosotros en Andalucía occidental. Madrid: Universidad Autónoma de Madrid.

Lara, V. 2012. "Ustedes instead of vosotros and vocês instead of vós: an analysis through the Linguistic Atlas of the Iberian Peninsula (ALPI)". Dialectologia Special Issue III: 57-93.

Lara, V. 2015. Los tratamientos de 2pl en Andalucía occidental y Portugal: estudio geo- y sociolingüístico de un proceso de gramaticalización. Ph.D. thesis, Madrid: Universidad Autónoma de Madrid.

Lara, V. 2016. "Spontaneous dubbing as a tool for eliciting linguistic data: the case of second person plural inflections in Andalusian Spanish". In Côte, M.H. et al. (eds.), The future of dialects: selected papers from Methods in Dialectology XV, 261 - 281. Language Variation Series. Berlin: Language Science Press.

Lehmann, W.P. 1975. "From topic to subject in Indo-European". In Li, Charles N. (ed.), Subject and topic, $445-456$. New York: Academic Press Inc.

Li, C. N. 1975. Subject and topic. New York: Academic Press Inc.

Menéndez Pidal, R. 2005. Historia de la lengua española. Madrid: RAE / Fundación Menéndez Pidal.

Olarrea, A. 1995. "Notes on the optionality of agreement". ASJU XXIX 1: 133 - 173.

Ordóñez, F. \& Treviño, E. 1999. "Left dislocated subjects and the pro drop parameter: a case study of Spanish". Lingua 107: 39 - 68.

https://doi.org/10.1016/s0024-3841(98)00020-5 
Papangeli, D. 2000. "Clitic doubling in Modern Greek: a head-complement relation". In Iten, C. \& Neeleman, A. (eds.), Ucl working papers in linguistics 12, vol. 12, 473-497. London: University College London.

Penny, R. 2004. Variación y cambio en español. Madrid: Gredos.

Real Academia Española \& Asociación de Academias de la Lengua Española. 2009. Nueva gramática de la lengua española. Madrid: Espasa.

Rizzi, L. 1997. "The fine structures of the left periphery". In Haegeman, L. (ed.), Elements of grammar, 281 - 337. Kluwer: Dordrecht. https://doi.org/10.1007/978-94-011-5420-8_1

Rodríguez Ramalle, T. M. 2005. Manual de sintaxis del español. Madrid: Castalia.

Rohlfs, G. 1968. Grammatica storica della lingua italiana e dei suoi dialetti. Torino: Einaudi.

Rubio Alcalá, C. 2014. Syntactic constraints on topicalization phenomena. Ph.D. thesis, Barcelona: Universitat Autònoma de Barcelona.

Schachter, P. 1975. "The subject in Philippine languages: topic, actor, actor-topic, or none of the above". In Li, C. N. (ed.), Subject and topic, 491 - 518. New York: Academic Press Inc.

Uriagereka, J. 1993. "Specificity and the name constraint". University of Maryland working papers in linguistics 1: $121-143$.

Uriagereka, J. 1995. "Aspects of the syntax of clitic placement in Western romance". Linguistic Inquiry 26 (1): $79-123$.

Wolfram, W. \& Schilling-Estes, N. 2003. "Dialectology and Linguistic Diffusion". In Joseph, B.D. \& Janda, R.D. (eds.), The Handbook of Historical Linguistics, 713735. Malden: Blackwell.

https://doi.org/10.1111/b.9781405127479.2004.00012.x 